\title{
Evidence for calmodulin inter-domain compaction in solution induced by W-7 binding
}

\author{
Masanori Osawa ${ }^{\mathrm{a}, \mathrm{b}}$, Shigeo Kuwamoto ${ }^{\mathrm{c}}$, Yoshinobu Izumi ${ }^{\mathrm{c}}$, Kyoko L. Yap ${ }^{\mathrm{d}}$, \\ Mitsuhiko Ikura ${ }^{\mathrm{d}}$, Tadao Shibanuma ${ }^{\mathrm{a}}$, Hisayuki Yokokura ${ }^{\mathrm{e}}$, Hiroyoshi Hidaka ${ }^{\mathrm{e}}$, \\ Norio Matsushima ${ }^{\mathrm{f}, *}$ \\ ${ }^{a}$ Molecular Chemistry Research, Chemistry Laboratories, Institute for Drug Discovery Research, Yamanouchi Pharmaceutical Co., Ltd., \\ Tsukuba 305-8585 Japan \\ ${ }^{\mathrm{b}}$ Center for Tsukuba Advanced Research Alliance and Institute of Applied Biochemistry, University of Tsukuba, Tsukuba 305-0006, Japan \\ ${ }^{\mathrm{c}}$ Graduate School of Engineering, Yamagata University, Yonezawa 992-8510, Japan \\ ${ }^{\mathrm{d}}$ Division of Molecular and Structural Biology, Ontario Cancer Institute and Department of Medical Biophysics, University of Toronto, \\ Toronto, Ont. M5G 2M9, Canada \\ ${ }^{\mathrm{e}}$ Department of Pharmacology, Nagoya University School of Medicine, Nagoya 406-8550, Japan \\ ${ }_{\mathrm{f}}^{\mathrm{f}}$ School of Health Sciences, Sapporo Medical University, S-1, W-17, Sapporo 060-8556, Japan
}

Received 14 October 1998; received in revised form 23 November 1998

\begin{abstract}
Small-angle X-ray scattering and nuclear magnetic resonance were used to investigate the structural change of calcium-bound calmodulin $\left(\mathrm{Ca}^{2+} / \mathrm{CaM}\right)$ in solution upon binding to its antagonist, $N$-(6-aminohexyl)-5-chloro-1-naphthalenesulfonamide (W-7). The radius of gyration was $17.4 \pm 0.3 \AA$ for $\mathrm{Ca}^{2+} / \mathrm{CaM}-\mathrm{W}-7$ with a molar ratio of $1: 5$ and $20.3 \pm 0.7 \AA$ for $\mathrm{Ca}^{2+} / \mathrm{CaM}$. Comparison of the radius of gyration and the pair distance distribution function of the $\mathrm{Ca}^{2+} / \mathrm{CaM}-\mathrm{W}-7$ complex with those of other complexes indicates that binding of two W-7 molecules induces a globular shape for $\mathrm{Ca}^{2+} / \mathrm{CaM}$, probably caused by an inter-domain compaction. The results suggest a tendency for $\mathrm{Ca}^{2+} / \mathrm{CaM}$ to form a globular structure in solution, which is inducible by a small compound like W-7.
\end{abstract}

(c) 1999 Federation of European Biochemical Societies.

Key words: Calmodulin-W-7 complex; Small-angle X-ray scattering; Conformational change; Globular structure

\section{Introduction}

Calmodulin $(\mathrm{CaM})$ is a ubiquitous $\mathrm{Ca}^{2+}$-binding protein of 148 residues that regulates a variety of physiological processes in a $\mathrm{Ca}^{2+}$-dependent manner [1]. The regulation is achieved through the interaction of $\mathrm{Ca}^{2+}$-bound $\mathrm{CaM}\left(\mathrm{Ca}^{2+} / \mathrm{CaM}\right)$ with a large number of target enzymes [2-4]. The $\mathrm{Ca}^{2+} / \mathrm{CaM}$ molecule adopts an 'elongated' structure in which the two globular domains are connected by a highly flexible linker [5-11], while the structures of $\mathrm{Ca}^{2+} / \mathrm{CaM}$ complexed with a peptide from target enzymes assume a compact globular shape caused by the bending of the domain linker [12-14]. These structural studies suggest that the flexibility of the domain linker plays an important role in the target recognition.

\footnotetext{
*Corresponding author. Fax: (81) (11) 612-3617.

E-mail:matusima@shs.sapmed.ac.jp
}

Abbreviations: CaM, calmodulin; $\mathrm{Ca}^{2+} / \mathrm{CaM}$, calcium-bound $\mathrm{CaM}$; W-7, $N$-(6-aminohexyl)-5-chloro-1-naphthalenesulfonamide; SAXS, small-angle X-ray scattering; NMR, nuclear magnetic resonance; TFP, trifluoperazine, 10-[3-(4-methylpiperazin-1-yl)propyl]-2-(trifluoromethyl)-10H-phenothiazine; DMSO, dimethyl sulfoxide; $R_{\mathrm{g}}$, radius of gyration; $p(r)$, pair distance distribution function; HSQC, heteronuclear single quantum coherence; CT-HSQC, constant time HSQC; NOE, nuclear Overhauser enhancement; MLCK, myosin light chain kinase; CaM-KII, $\mathrm{Ca}^{2+} / \mathrm{CaM}$-dependent protein kinase II
CaM antagonists such as $N$-(6-aminohexyl)-5-chloro1-naphthalenesulfonamide (W-7) and 10-[3-(4-methylpiperazin-1-yl)propyl]-2-(trifluoromethyl)-10H-phenothiazine (trifluoperazine, TFP) have been used extensively to study $\mathrm{Ca}^{2+} / \mathrm{CaM}$-dependent activation of various enzymes (Fig. 1). $\mathrm{X}$-ray crystal structure analysis revealed that $\mathrm{Ca}^{2+} / \mathrm{CaM}-\mathrm{TFP}$ complexes $(\mathrm{CaM}: \mathrm{TFP}=1: 1$ and $1: 4)$ adopt a globular structure similar to that of $\mathrm{Ca}^{2+} / \mathrm{CaM}$-target peptide complexes [12-16]. NMR analyses demonstrated that two antagonist molecules bind to one $\mathrm{Ca}^{2+} / \mathrm{CaM}$ molecule with high affinity $[17,18]$. However, the lack of NOEs between the two domains precluded the determination of their relative orientation [18]. In order to investigate whether the binding of $\mathrm{W}-7$ induces a globular structure similar to the $\mathrm{Ca}^{2+} / \mathrm{CaM}$-TFP complex, we applied small-angle X-ray scattering (SAXS) as well as NMR spectroscopy. The results provide evidence that a small organic compound such as W-7 can induce inter-domain compaction of $\mathrm{Ca}^{2+} / \mathrm{CaM}$ even in solution.

\section{Materials and methods}

\subsection{Sample preparation}

$\mathrm{W}-7$ was synthesized in bulk in the previous study and was carefully stored in our laboratory [19]. Uniformly ${ }^{13} \mathrm{C} /{ }^{15} \mathrm{~N}$-labeled or non-labeled recombinant Xenopus laevis CaM was expressed in Escherichia coli and purified to homogeneity as previously described [20]. For SAXS experiments, non-labeled CaM was dissolved in PIPES buffer ( $50 \mathrm{mM}$ PIPES-NaOH, $\mathrm{pH}$ 6.5), followed by dialysis against the buffer containing $10 \mathrm{mM} \mathrm{CaCl}_{2}$. The protein concentration was examined by the method of Bradford [21]. The W-7 powder was dissolved in dimethyl sulfoxide (DMSO) and added to the CaM solution. The final concentration of DMSO was set to $1 \%(\mathrm{v} / \mathrm{v})$ for all samples. The solutions for $\mathrm{Ca}^{2+} / \mathrm{CaM}$ and $\mathrm{Ca}^{2+} / \mathrm{CaM}$ complexed with five equivalents of W-7 were prepared at protein concentrations of 6.0, 9.0, 12.0, and $16.2 \mathrm{mg} / \mathrm{ml}$. Moreover, solutions for the $\mathrm{Ca}^{2+} / \mathrm{CaM}-\mathrm{W}-7$ mixtures with molar ratios of $1: 1,1: 2,1: 3$, and $1: 4$ were each prepared at a protein concentration of $9.0 \mathrm{mg} / \mathrm{ml}$. For NMR experiments, ${ }^{13} \mathrm{C} /{ }^{15} \mathrm{~N}$ labeled $\mathrm{CaM}$ was dissolved in unbuffered $0.4 \mathrm{ml} 95 \% \mathrm{H}_{2} \mathrm{O} / 5 \% \mathrm{D}_{2} \mathrm{O}$ or $99.99 \% \mathrm{D}_{2} \mathrm{O}$ solution containing $0.1 \mathrm{M} \mathrm{KCl}$ and $10.6 \mathrm{mM} \mathrm{CaCl}_{2}$. The $\mathrm{pH} / \mathrm{pD}$ values of the samples were 6.8 without consideration of isotope effects. The protein concentration was $1.5 \mathrm{mM}$.

\subsection{Small-angle X-ray scattering}

The measurements were performed using synchrotron orbital radiation with an instrument for SAXS installed at BL-10C of Photon Factory, Tsukuba [22]. An X-ray wavelength of $1.488 \AA$ was selected. The samples were contained in a quartz cell with a volume of $80 \mu \mathrm{l}$, and the temperature was maintained at $35 \pm 0.1^{\circ} \mathrm{C}$ by circulating water 
through the sample holder. The reciprocal parameter, $Q$, equal to $4 \pi \sin \theta / \lambda$, was calibrated by the observation of peaks from dried chicken collagen, where $2 \theta$ is the scattering angle and $\lambda$ is the X-ray wavelength. Scattering data were collected for $600 \mathrm{~s}$ at individual protein concentrations and for $1800 \mathrm{~s}$ at only $6.0 \mathrm{mg} / \mathrm{ml}$.

Two methods of data analysis were used. The first method is that of Guinier [23] which gives the radius of gyration, $R_{\mathrm{g}}$. The range of $Q$ $\left(\AA^{-1}\right)$ used for Guinier plots was $3.44 \times 10^{-2}$ to $6.88 \times 10^{-2}$. The second method is the calculation of pair distance distribution function, $p(r)$, which is the frequency of the distances $r$ within a macromolecule obtained by combining any volume element with any other volume element [24]. The $p(r)$ is calculated by a direct Fourier transformation [24]. Data to $Q\left(\AA^{-1}\right)=0.7$ were used for $p(r)$ analysis. The maximal pair distance, $d_{\max }$, was also estimated from the $p(r)$ function; $p(r)$ becomes zero at values of $r$ equal to or greater than the maximum $d_{\max }$ of the particle. Furthermore, $R_{\mathrm{g}}$ and $p(r)$ were calculated from atomic coordinates of the $\mathrm{Ca}^{2+} / \mathrm{CaM}$-TFP complexes in order to compare the X-ray values for the $\mathrm{Ca}^{2+} / \mathrm{CaM}-\mathrm{W}-7$ complex. Details of the calculation method are given elsewhere $[25,26]$.

\subsection{NMR spectroscopy}

All of the NMR spectra were measured at $35^{\circ} \mathrm{C}$ on a Bruker AMX600 spectrometer. W-7 was titrated in aliquots of 0.33 protein equivalent into a uniformly ${ }^{13} \mathrm{C} /{ }^{15} \mathrm{~N}$-labeled sample of the protein. After the addition of each aliquot of $\mathrm{W}-7,1 \mathrm{D}{ }^{1} \mathrm{H}, 2 \mathrm{D}{ }^{15} \mathrm{~N}-{ }^{1} \mathrm{H}$ HSQC $[27,28]$, and $2 \mathrm{D}^{13} \mathrm{C}-{ }^{-1} \mathrm{H}$ CT-HSQC [29] spectra were acquired. Finally, spectra with $0,0.33,0.66,1.0,1.33,1.66,2.0,2.5,3.0,3.5,4.0,5.0$, and 6.0 equivalents of W-7 to CaM were recorded. Spectral changes for $2 \mathrm{D}$ ${ }^{13} \mathrm{C}-{ }^{1} \mathrm{H}$ CT-HSQC were previously reported [18].

\section{Results}

\subsection{The radius of gyration and the $p(r)$ function}

Fig. 2 shows the Guinier plots for $\mathrm{Ca}^{2+} / \mathrm{CaM}$ alone and $\mathrm{Ca}^{2+} / \mathrm{CaM}$ in the presence of $\mathrm{W}-7$ with the molar ratio of $1: 5$ at four protein concentrations. $R_{\mathrm{g}}$ as a function of protein is shown in Fig. 3. $R_{\mathrm{g}}$ values of the $\mathrm{Ca}^{2+} / \mathrm{CaM}-\mathrm{W}-7$ complex and $\mathrm{Ca}^{2+} / \mathrm{CaM}$ at zero concentration are given in Table 1 . For comparison, Table 1 also contains $R_{\mathrm{g}}$ values for other $\mathrm{Ca}^{2+} / \mathrm{CaM}$ complexes reported by other researchers. The $R_{\mathrm{g}}$ value for $\mathrm{Ca}^{2+} / \mathrm{CaM}-\mathrm{W}-7$ complex $(17.4 \pm 0.3 \AA$ ) is comparable to the calculated $R_{\mathrm{g}}$ from atomic coordinates of $\mathrm{Ca}^{2+}$ / CaM-TFP complex $(1: 4)$ which is smaller due to the lack of atomic coordinates for the first two residues [16]. It is also consistent or comparable to $R_{\mathrm{g}}$ values of other $\mathrm{Ca}^{2+} / \mathrm{CaM}$ complexes containing mastoparan [25,30], melittin [31], cyclosporin-A [32], substance $\mathrm{P}$ [33] and respective synthetic peptide corresponding to the calmodulin-binding domains of MLCK (M13) [34], phosphorylase kinase (RhK5) [35] and $\mathrm{Ca}^{2+}$ pump (C24W) [36]. The $R_{\mathrm{g}}$ value for $\mathrm{Ca}^{2+} / \mathrm{CaM}$ $(20.3 \pm 0.7 \AA)$ is also comparable to the values reported previously [25,31-36]. Fig. 4 shows $R_{\mathrm{g}}$ values as a function of molar ratio of $\mathrm{Ca}^{2+} / \mathrm{CaM}$ and $\mathrm{W}-7$ at $9.0 \mathrm{mg} / \mathrm{ml}$. A drastic<smiles>NCCCCCCNS(=O)(=O)c1cccc2c(Cl)cccc12</smiles>

(a) W-7<smiles>CN1CCN(CCCN2c3ccccc3Sc3ccc(C(F)(F)F)cc32)CC1</smiles>

(b) TFP
Fig. 1. Chemical structures of W-7 and TFP.
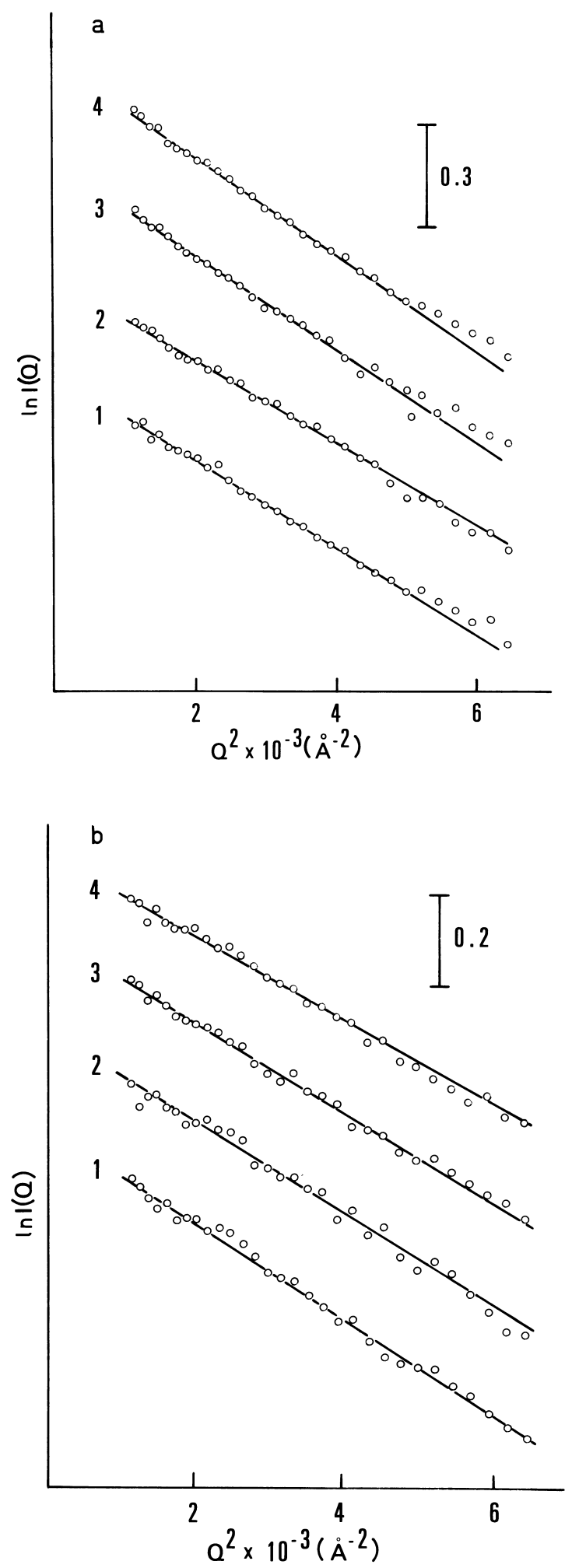

Fig. 2. Guinier plots for $\mathrm{Ca}^{2+} / \mathrm{CaM}-\mathrm{W}-7$ complex $\left(\mathrm{Ca}^{2+} / \mathrm{CaM}: \mathrm{W}-\right.$ $7=1: 5)$ and $\mathrm{Ca}^{2+} / \mathrm{CaM}$ at various protein concentrations. a: $\mathrm{Ca}^{2+} /$ CaM-W-7 complex. b: $\mathrm{Ca}^{2+} / \mathrm{CaM} .1,6.0 \mathrm{mg} / \mathrm{ml} ; 2,9.0 \mathrm{mg} / \mathrm{ml}$; $3,12.0 \mathrm{mg} / \mathrm{ml} ; 4,16.2 \mathrm{mg} / \mathrm{ml}$.

decrease in the $R_{\mathrm{g}}$ upon W-7 binding to $\mathrm{Ca}^{2+} / \mathrm{CaM}$ finishes at the ratio of $1: 2$.

Fig. 5 shows the $p(r)$ functions for $\mathrm{Ca}^{2+} / \mathrm{CaM}$ alone and $\mathrm{Ca}^{2+} / \mathrm{CaM}$ in the presence of $\mathrm{W}-7$. The $p(r)$ function for the 


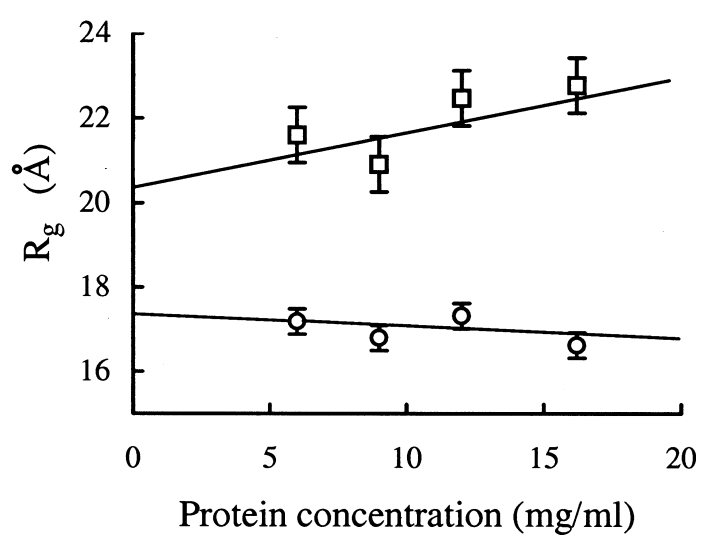

Fig. 3. The radius of gyration, $R_{\mathrm{g}}$, for $\mathrm{Ca}^{2+} / \mathrm{CaM}-\mathrm{W}-7$ complex $\left(\mathrm{Ca}^{2+} / \mathrm{CaM}: \mathrm{W}-7=1: 5\right)$ and $\mathrm{Ca}^{2+} / \mathrm{CaM}$ as a function of the protein concentration. $\bigcirc, \mathrm{Ca}^{2+} / \mathrm{CaM}-\mathrm{W}-7$ complex; $\square, \mathrm{Ca}^{2+} / \mathrm{CaM}$.

$\mathrm{Ca}^{2+} / \mathrm{CaM}$ alone has a peak near $20 \AA$ (principally representing interatomic distances within each domain of $\mathrm{Ca}^{2+} / \mathrm{CaM}$ ) and a shoulder at near $40 \AA$ (mainly representing inter-domain distances) [7,25]. By contrast, the shoulder near $40 \AA$ disappears for the $\mathrm{Ca}^{2+} / \mathrm{CaM}-\mathrm{W}-7$ complex. Its $d_{\max }$ is about $14 \AA$ smaller than that for the $\mathrm{Ca}^{2+} / \mathrm{CaM}$ alone. These characteristic behaviors are also seen in the $p(r)$ function calculated from the atomic coordinates of the crystal structure of $\mathrm{Ca}^{2+} / \mathrm{CaM}-\mathrm{TFP}$ complex $[15,16]$ and from the SAXS profiles of other complexes including $\mathrm{Ca}^{2+} / \mathrm{CaM}-\mathrm{M} 13$ complex $[25,31,32,34-36]$. The determination of the three-dimensional structure indicated that $\mathrm{Ca}^{2+} / \mathrm{CaM}-\mathrm{TFP}$ and -M13 complexes are in a globular form. Thus, the present data indicate that $\mathrm{Ca}^{2+} / \mathrm{CaM}$ complexed with $\mathrm{W}-7$ adopts a globular structure similar to those of other complexes.

\subsection{NMR spectral changes}

The NMR spectral changes in the ${ }^{15} \mathrm{~N}-{ }^{1} \mathrm{H}$ HSQC spectra of uniformly ${ }^{13} \mathrm{C} /{ }^{15} \mathrm{~N}$-labeled $\mathrm{CaM}$ were monitored upon addition of unlabeled W-7. Fig. 6 shows the selected portions of the spectra for $\mathrm{Ca}^{2+} / \mathrm{CaM}: \mathrm{W}-7$ molar ratios from $1: 0$ to $1: 3$. Most of the HSQC peaks in each of the two CaM domains (Ala-1 to Lys-75, Glu-82 to Lys-148) were gradually shifted with little change in their intensities, indicating that the conformational exchange rate between $\mathrm{W}-7$ bound state and unbound state is fast on the NMR time scale. In contrast, the

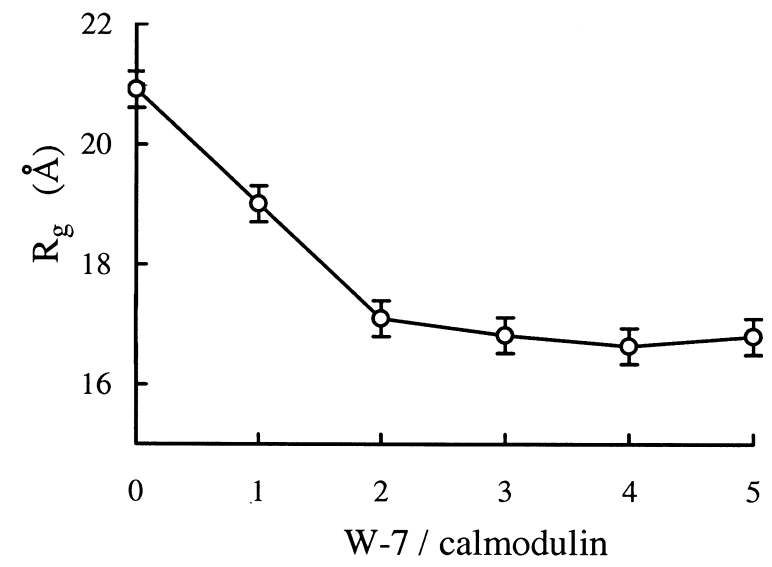

Fig. 4. The radius of gyration, $R_{\mathrm{g}}$, as a function of the molar ratio of W-7 to $\mathrm{Ca}^{2+} / \mathrm{CaM}$ at the protein concentration of $9.0 \mathrm{mg} / \mathrm{ml}$.

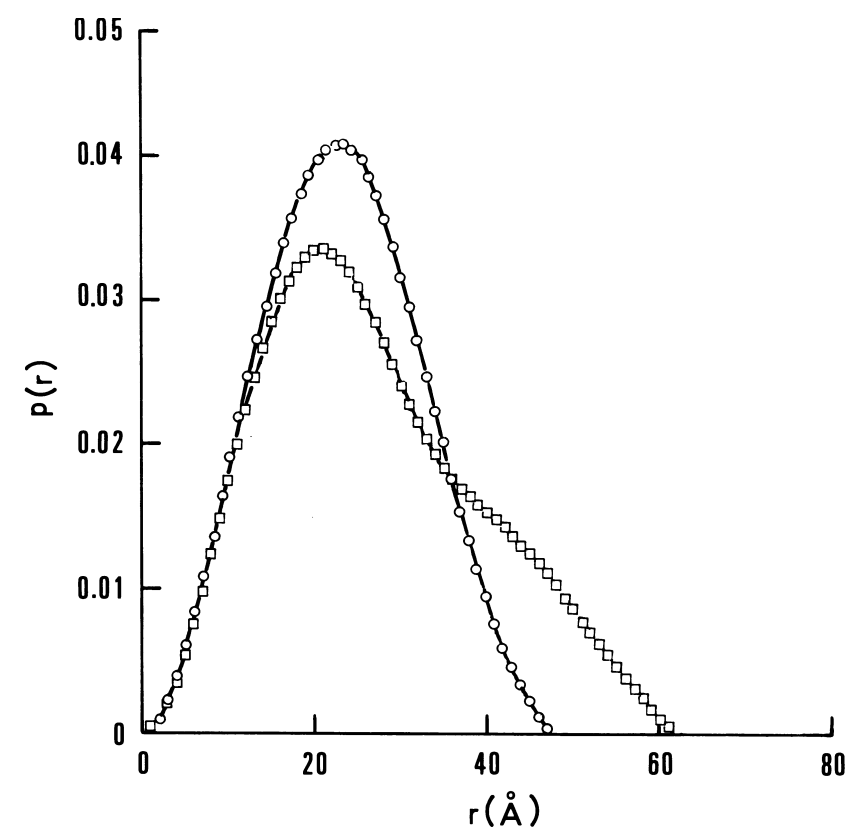

Fig. 5. Pair distance distribution function, $p(r)$, for $\mathrm{Ca}^{2+} / \mathrm{CaM}-\mathrm{W}-7$ complex $\left(\mathrm{Ca}^{2+} / \mathrm{CaM}: \mathrm{W}-7=1: 5\right)$ and $\mathrm{Ca}^{2+} / \mathrm{CaM} . \bigcirc, \mathrm{Ca}^{2+} / \mathrm{CaM}-\mathrm{W}-7$ complex; $\square, \mathrm{Ca}^{2+} / \mathrm{CaM}$.

signals from Met-76, Asp-78, Thr-79, Asp-80, Ser-81 and Glu82 in the domain linker are broadened upon addition of W-7. This broadening indicates that the conformational exchange rate of the linker is slower than that in each domain.

\section{Discussion}

\subsection{Globular structure of $\mathrm{Ca}^{2+} / \mathrm{CaM}-W-7$ complex}

The SAXS analysis shows that the binding of two W-7 molecules induces drastic structural change in $\mathrm{Ca}^{2+} / \mathrm{CaM}$; the overall shape changes from an elongated structure to a compact globular structure in solution. Our previous NMR analysis [18] showed that the backbone conformation in each $\mathrm{CaM}$ domain remains essentially unchanged upon binding of

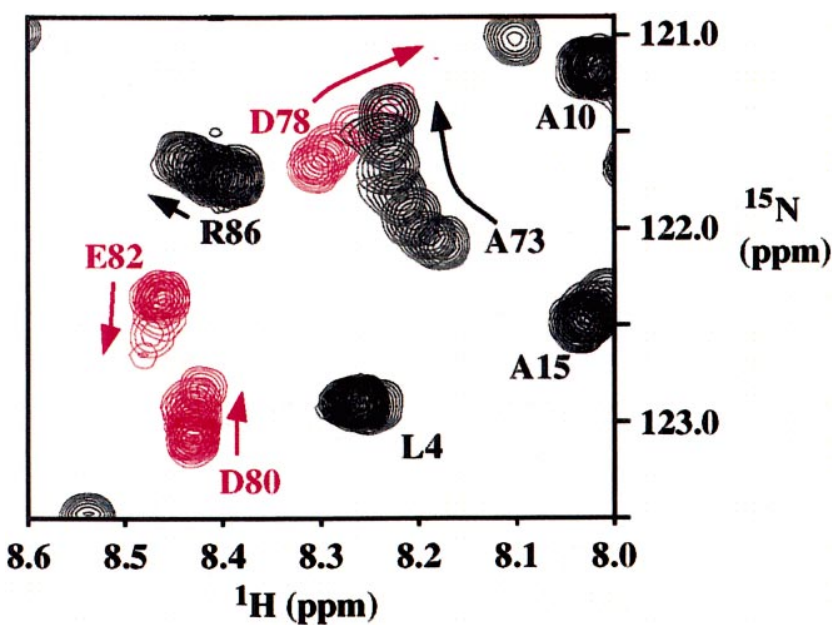

Fig. 6. NMR spectral changes for $\mathrm{Ca}^{2+} / \mathrm{CaM}$ amide groups upon W-7 binding. Spectra of the same region, which are for $\mathrm{Ca}^{2+} / \mathrm{CaM}-$ $\mathrm{W}-7=1: 0,1: 0.33,1: 0.66,1: 1,1: 2,1: 3$, were superimposed. NMR signals in each CaM domain and in the domain linker are drawn in black and red, respectively. 
Table 1

Radius of gyration $R_{\mathrm{g}}$ and maximum dimension $d_{\max }$ for $\mathrm{Ca}^{2+} / \mathrm{CaM}$ and its complexes

\begin{tabular}{|c|c|c|}
\hline & $R_{\mathrm{g}}[\mathrm{A}]$ & $d_{\max }[\AA]$ \\
\hline $\mathrm{Ca}^{2+} / \mathrm{CaM}^{\mathrm{a}}$ & $20.3 \pm 0.7$ & 61 \\
\hline $\mathrm{Ca}^{2+} / \mathrm{CaM}-\mathrm{W}-7^{\mathrm{a}}$ & $17.4 \pm 0.3$ & 47 \\
\hline $\mathrm{Ca}^{2+} / \mathrm{CaM}^{\mathrm{a}}[31]$ & $20.17 \pm 0.16$ & 62.5 \\
\hline $\mathrm{Ca}^{2+} / \mathrm{CaM}^{\mathrm{a}}[25]$ & $21.5 \pm 0.3$ & 69 \\
\hline $\mathrm{Ca}^{2+} / \mathrm{CaM}^{\mathrm{a}}[36]$ & $21.36 \pm 0.10$ & $62.5 \pm 2.5$ \\
\hline $\mathrm{Ca}^{2+} / \mathrm{CaM}-\mathrm{TFP}^{\mathrm{b}}[16]$ & 15.92 & 46.0 \\
\hline $\mathrm{Ca}^{2+} / \mathrm{CaM}-\mathrm{M} 13^{\mathrm{a}}[34]$ & $16.4 \pm 0.2$ & 49 \\
\hline $\mathrm{Ca}^{2+} / \mathrm{CaM}-\mathrm{RhK} 5^{\mathrm{a}}[35]$ & $17.3 \pm 0.2$ & 49 \\
\hline $\mathrm{Ca}^{2+} / \mathrm{CaM}-\mathrm{C} 24 \mathrm{~W}^{\mathrm{a}}[36]$ & $17.2 \pm 0.3$ & $52.5 \pm 2.5$ \\
\hline $\mathrm{Ca}^{2+} / \mathrm{CaM}$-mastoparan ${ }^{\mathrm{a}}[25]$ & $17.8 \pm 0.3$ & 55 \\
\hline $\mathrm{Ca}^{2+} / \mathrm{CaM}-$ melittin ${ }^{\mathrm{a}}[31]$ & $17.85 \pm 0.13$ & 47.5 \\
\hline $\mathrm{Ca}^{2+} / \mathrm{CaM}$-substance $\mathrm{P}^{\mathrm{a}}[33]$ & $17.2 \pm 0.3$ & - \\
\hline
\end{tabular}

${ }^{a}$ Values at zero protein concentration obtained by SAXS experiment.

${ }^{b}$ Values calculated from the atomic coordinates of the crystal structure.

W-7. However, line broadening of NMR signals was observed for the residues of the domain linker (Met-76, Asp-78, Thr-79, Asp-80, Ser-81 and Glu-82) upon W-7 binding. Thus, it is likely that the globular structure is caused by bending of the flexible linker. A similar bending was observed in the crystal structure of $\mathrm{Ca}^{2+} / \mathrm{CaM}-\mathrm{TFP}$ complex $[15,16]$, and in both solution and crystal structures of $\mathrm{Ca}^{2+} / \mathrm{CaM}$ complexed with a peptide from skeletal muscle and smooth muscle MLCK and brain CaM-KII [12-14]. The previous NMR study [18] showed no inter-domain NOE in $\mathrm{Ca}^{2+} / \mathrm{CaM}$ complexed with $\mathrm{W}-7$, suggesting that the relative orientation of the two domains is not always fixed due to a conformational change between various orientations. However, the SAXS data indicate that the time- and spatially averaged shape of the $\mathrm{Ca}^{2+}$ / CaM-W-7 complex represents a compact, globular one. The lack of NOE is consistent with the notion that the inter-domain interaction is unstable and involves a rapid exchange between the associated and dissociated states. Evidence for the inter-domain interaction of $\mathrm{CaM}$ has been obtained by proteolytic footprinting studies [37], in which a conformational state with a short life-time could be trapped.

The NMR structure of $\mathrm{Ca}^{2+} / \mathrm{CaM}-\mathrm{W}-7$ complex suggested that W-7 inhibits the CaM-mediated activation of target proteins by blocking the hydrophobic pocket [18]. The present results show that binding of two W-7 molecules induces compaction between the two domains of CaM. In addition to the direct interaction of $\mathrm{W}-7$ with the hydrophobic pocket of $\mathrm{Ca}^{2+} / \mathrm{CaM}$, the induced globular structure of $\mathrm{Ca}^{2+} / \mathrm{CaM}$ might also contribute to inhibition of activity, since the CaM binding region of the target enzyme becomes less accessible to $\mathrm{Ca}^{2+} / \mathrm{CaM}$ in the compact conformation.

\subsection{Comparison with globular structure of $\mathrm{Ca}^{2+} / \mathrm{CaM}-\mathrm{TFP}$ complex}

An inter-domain compaction of $\mathrm{Ca}^{2+} / \mathrm{CaM}$ has been observed previously in the crystal structures of the $\mathrm{Ca}^{2+} / \mathrm{CaM}$ TFP complex $[15,16]$. There are differences in the TFP binding stoichiometry between the two structures (CaM:TFP $=1: 1$ and $1: 4$ ), probably due to differences in the crystallization conditions. On the other hand, the NMR signals of both CaM domains moved by similar amounts during the addition of the first two equivalents of TFP, suggesting that the binding affinities of either CaM domain to TFP is indistinguishable in solution [17]. Thus, it has been unclear yet how many
TFP molecules induce an inter-domain compaction of CaM in solution. However, both crystal structures show a similar CaM conformation induced by TFP binding (backbone superposition of the two structures using CaM residues 9-73 and 84-145 gives a RMS deviation value of $0.39 \AA$ ), prompting us to use both structures for comparison.

Although the chemical structure of W-7 differs from that of TFP, both contain a hydrophobic aromatic group with positively charged group via the aliphatic chain (Fig. 1). In the $\mathrm{Ca}^{2+} / \mathrm{CaM}-\mathrm{W}-7$ complex, the naphthalene ring of the two W7 molecules interact intimately with the hydrophobic pocket of the two CaM domains [18], whereas only one end of TFP phenothiazine ring is inserted into the pocket of $\mathrm{Ca}^{2+} / \mathrm{CaM}$ TFP complex $[15,16]$. This hydrophobic pocket can accommodate van der Waals contacts with such chemically different groups. This high adaptability of the CaM hydrophobic pocket originates from highly abundant methionine residues with a flexible and polarizable side chain [18].

It has been suggested that positively charged nitrogen atoms of the TFP piperazine group participate in electrostatic interactions with negatively charged residues of $\mathrm{Ca}^{2+} / \mathrm{CaM}$ such as Glu-127, reducing an electrostatic repulsion between both domains [16]. Similarly, electrostatic interactions between the positively charged nitrogen atom of the W-7 aminohexyl group and negatively charged residues within $\mathrm{Ca}^{2+}$ / CaM may contribute to the stabilization of the globular structure in the complex. Most probable partners in CaM include Glu-14 and Glu-54 in the N-terminal domain and Glu-87, Glu-114, and Glu-127 in the C-terminal domain.

The methylene groups of $\mathrm{W}-7$ in the $\mathrm{Ca}^{2+} / \mathrm{CaM}-\mathrm{W}-7$ complex were suggested to be unimportant in the specific interactions with $\mathrm{Ca}^{2+} / \mathrm{CaM}$ [18]. However, it is noted that the number of the methylene groups in $\mathrm{W}-7$ derivatives is proportional to their binding affinity to $\mathrm{Ca}^{2+} / \mathrm{CaM}$ [38]. In the structure of $\mathrm{Ca}^{2+} / \mathrm{CaM}-\mathrm{TFP}$ complex, the methylene groups of TFP make contacts with the hydrophobic side chains of $\mathrm{Ca}^{2+} / \mathrm{CaM}$ around the hydrophobic pockets. Similarly, the methylene groups of W-7 might contribute to the W-7 binding to $\mathrm{Ca}^{2+} / \mathrm{CaM}$ by van der Waals interactions.

\subsection{Comparison with $\mathrm{Ca}^{2+} / \mathrm{CaM}$-target peptide complex}

The globular structures of $\mathrm{Ca}^{2+} / \mathrm{CaM}$ in complex with its target peptide from skeletal/smooth muscle MLCK or brain CaM-KII are stabilized by extensive van der Waals interac- 
tions in addition to electrostatic interactions, where the target peptide forming $\alpha$-helix binds to both the CaM domains simultaneously [12-14]. In contrast, a similar globular structure of $\mathrm{Ca}^{2+} / \mathrm{CaM}$ is induced by the main interaction of $\mathrm{W}-7$ with the hydrophobic pocket of each CaM domain, though the relative orientation of the two domains is not always fixed. This is reflected in the binding affinity of $\mathrm{W}-7$ to $\mathrm{Ca}^{2+} / \mathrm{CaM}$, which is about $10^{3}$ times lower than the binding affinity of the target peptides [38-42]. Thus it is indicated that such weaker interactions as those of W-7 can induce the globular structure of $\mathrm{Ca}^{2+} / \mathrm{CaM}$ in solution and, therefore, the bridging of both domains by a polypeptide chain of the target molecule is not necessary for the formation of the globular structure.

\subsection{Conclusion}

The present SAXS results indicate that the binding of small organic compound $\mathrm{W}-7$ to $\mathrm{Ca}^{2+} / \mathrm{CaM}$ induces a globular structure in solution, which is suggested to be caused by the bending of the flexible domain linker of $\mathrm{Ca}^{2+} / \mathrm{CaM}$. In contrast to the fixed orientation of the two CaM domains bound to a target peptide, the relative orientation of the CaM domains is flexible in the $\mathrm{Ca}^{2+} / \mathrm{CaM}-\mathrm{W}-7$ complex, though the time-averaged shape remains globular and compact. These results indicate that the dynamics and relative orientation of two CaM domains can vary significantly in solution upon binding to various target molecules including antagonists such as W-7.

Acknowledgements: We are grateful to Claude Klee for kindly providing the Xenopus calmodulin expression system. This work was supported in part by grants (to M.I.) from the Medical Research Council of Canada (MRCC) and by the Suhara foundation (to N.M.). M.I. is a Howard Hughes Medical Institute International Research Scholar. Small-angle X-ray scattering measurement was performed under approval of the Photon Factory Advisory Committee (Proposal No. 98G202).

\section{References}

[1] Eldik, L.J.V. and Watterson, D.M. (1998) Calmodulin and Calcium Signal Transduction, Academic Press, San Diego, CA.

[2] Means, A.R., VanBerkum, M.F.A., Bagchi, I., Lu, K.P. and Rasmussen, C.D. (1991) Pharmacol. Ther. 50, 255-270.

[3] Vogel, H.J. (1994) Biochem. Cell. Biol. 72, 357-376.

[4] James, P., Vorherr, T. and Carafoli, E. (1995) Trends Biochem. Sci. 20, 38-42.

[5] Finn, B.E., Evenas, J., Drakenberg, T., Waltho, J.P., Thulin, E. and Forsen, S. (1995) Nature Struct. Biol. 2, 777-783.

[6] Kretsinger, R.H., Rudnick, S.E. and Weissman, L.J. (1986) J. Inorg. Biochem. 28, 289-302.

[7] Seaton, B.A., Head, J.F., Engelman, D.M. and Richards, F.M. (1985) Biochemistry 24, 6740-6743.

[8] Heidorn, D.B., Seeger, P.A., Rokop, S.E., Blumenthal, D.K., Means, A.R., Crespi, H. and Trewhella, J. (1989) Biochemistry 28, 6757-6764.

[9] Persechini, A. and Kretsinger, R.H. (1988) J. Biol. Chem. 263, 12175-12178.

[10] Barbato, G., Ikura, M., Kay, L.E., Pastor, R.W. and Bax, A. (1992) Biochemistry 31, 5269-5278.
[11] Spoel, D.V.D., De Groot, B.L., Heyward, S., Berendsen, H.J.C. and Vogel, H.J. (1996) Protein Sci. 5, 2044-2053.

[12] Ikura, M., Clore, G.M., Gronenborn, A.M., Zhu, G., Klee, C.B. and Bax, A. (1992) Science 256, 632-638.

[13] Meador, W.E., Means, A.R. and Quiocho, F.A. (1992) Science $257,1251-1255$.

[14] Meador, W.E., Means, A.R. and Quiocho, F.A. (1993) Science $262,1718-1721$.

[15] Cook, W.J., Walter, L.J. and Walter, M.R. (1994) Biochemistry $33,15259-15265$.

[16] Vandonselaar, M., Hickie, R.A., Quail, J.W. and Delbaere, L.T.J. (1994) Nature Struct. Biol. 1, 795-801.

[17] Craven, C.J., Whitehead, B., Jones, K.A., Thulin, S.E., Blackburn, G.M. and Waltho Jr., P. (1996) Biochemistry 35, $10287-$ 10299.

[18] Osawa, M., Swindells, M.B., Tanikawa, J., Tanaka, T., Mase, T., Furuya, T. and Ikura, M. (1998) J. Mol. Biol. 276, 165-176.

[19] Hidaka, H., Asano, M., Iwadate, S., Matsumoto, I., Totsuka, R. and Aoki, N.J. (1978) Pharmacol. Exp. Ther. 207, 8-15.

[20] Ikura, M., Kay, L.E. and Bax, A. (1990) Biochemistry 29, 46594667.

[21] Bradford, M. (1976) Anal. Biochem. 72, 248-254.

[22] Ueki, T., Hiragi, Y., Kataoka, M., Inoko, Y., Amemiya, Y., Izumi, Y., Tagawa, H. and Muroga, Y. (1985) Biophys. Chem. $23,115-124$.

[23] Guinier, A. (1939) Ann. Phys. 12, 166-237.

[24] Glatter, O. (1982) in: Data Analysis (Glatter, O. and Kratky, O., Eds.), pp. 119-196, Academic Press, New York.

[25] Matsushima, N., Izumi, Y., Matsuo, T., Yoshino, H., Ueki, T. and Miyake, Y. (1989) J. Biochem. 105, 883-887.

[26] Matsushima, N., Izumi, Y. and Aoba, T. (1998) J. Biochem. 123, $150-156$.

[27] Palmer III, A.G., Cavanagh, J., Wright, P.E. and Rance, M. (1991) J. Magn. Reson. 93, 151-170.

[28] Kay, L.E., Keifer, P. and Saarinen, T. (1992) J. Am. Chem. Soc. $114,10663-10665$.

[29] Vuister, G.W. and Bax, A. (1992) J. Magn. Reson. 98, 428-435.

[30] Yoshino, H., Minari, O., Matsushima, N., Ueki, T., Miyake, Y., Matsuo, T. and Izumi, Y. (1989) J. Biol. Chem. 264, 1970619709.

[31] Kataoka, M.M., Vogel, H.J., Seaton, B.A. and Engelman, D.M. (1989) Proc. Natl. Acad. Sci. USA 86, 6944-6948.

[32] Knott, R., Hansen, S. and Henderson, S. (1994) J. Struct. Biol. 112, 192-198.

[33] Yoshino, H., Wakita, M. and Izumi, Y. (1993) J. Biol. Chem. 268, 12123-12128.

[34] Heidorn, D.B., Seeger, P.A., Rokop, S.E., Blumenthal, D.K., Means, A.R., Crespi, H. and Trewhella, J. (1989) Biochemistry $28,6757-6764$.

[35] Trewhella, J., Blumenthal, D.K., Rokop, S.E. and Seeger, P.A. (1990) Biochemistry 29, 9316-9324.

[36] Kataoka, M., Head, J.F., Vorherr, T., Krebs, J. and Carafoli, E. (1991) Biochemistry 30, 6247-6251.

[37] Pedigo, S. and Shea, M.A. (1995) Biochemistry 34, 1179-1196.

[38] Tanaka, T., Ohmura, T. and Hidaka, H. (1982) Mol. Pharmacol. 22, 403-407.

[39] Hidaka, H., Yamaki, T., Naka, M., Tanaka, T., Hayashi, H. and Kobayashi, R. (1979) Mol. Pharmacol. 17, 66-72.

[40] Levin, R.M. and Weiss, B. (1977) Mol. Pharmacol. 13, 690-697.

[41] Massom, L., Lee, H. and Jarrett, H.W. (1990) Biochemistry 29, 671-681.

[42] Blumenthal, D.K., Takio, K., Edelman, A.M., Charbonneau, H., Titani, K., Walsh, K.A. and Krebs, E.G. (1985) Proc. Natl. Acad. Sci. USA 82, 3187-3191. 